\title{
Changes in glacier dynamics under the influence of proglacial lake formation in Rhonegletscher, Switzerland
}

\author{
Shun TSUTAKI, ${ }^{1,2}$ Daisuke NISHIMURA, ${ }^{1,2}$ Takeshi YOSHIZAWA, ${ }^{1,2}$ Shin SUGIYAMA ${ }^{2}$ \\ ${ }^{1}$ Graduate School of Environmental Science, Hokkaido University, Sapporo 060-0810, Japan \\ E-mail: tsuta@lowtem.hokudai.ac.jp \\ ${ }^{2}$ Institute of Low Temperature Science, Hokkaido University, Sapporo 060-0819, Japan
}

\begin{abstract}
To investigate the impact of proglacial lake formation on the dynamics and evolution of glaciers, we measured the ice motion of the terminal part of Rhonegletscher, Switzerland, where a lake formed in 2005. In 2009, the flow velocity near the terminus was $>20 \mathrm{~m} \mathrm{a}^{-1}$. One of the survey stakes tripled its velocity between 2006 and 2007 . Since the lake water pressure was consistently close to the ice overburden pressure, it is likely that the high subglacial water pressure enhanced the basal ice motion. The estimated flow velocity due to ice shearing was negligibly small; almost $100 \%$ of the horizontal velocity near the terminus was caused by basal sliding. The longitudinal strain rate was large, $0.064 \mathrm{a}^{-1}$, indicating that much of the glacier thinning was due to ice dynamics. The region of ice flotation adjacent to the lake expanded between 2008 and 2009 as a result of glacier thinning. Accordingly, a huge uplift of the surface was observed in 2009. It is clear from the vertical ice motion as well as visual observations that the marginal part of the glacier began to float. The ice-thinning rate in the studied area from 2008 to 2009 was $3.4 \mathrm{~m} \mathrm{a}^{-1}$, larger than previous estimates.
\end{abstract}

\section{INTRODUCTION}

A number of proglacial lakes formed and expanded in temperate valley glaciers during the 20th century as a result of glacier thinning linked to climate change (e.g. Kirkbride and Warren, 1999; Boyce and others, 2007). Proglacial lakes pose a threat to human activity due to the possibility of a glacier lake outburst flood (GLOF) (see Post and Mayo, 1971; Yamada, 1998; Clague and Evans, 2000). Furthermore, previous studies suggest that lake formation increases the rate of glacier retreat (e.g. Funk and Röthlisberger, 1989; Naruse and Skvarca, 2000; Müller, 2004). When a lake forms at its terminus, the bed is lubricated and the basal ice motion is enhanced. Investigations at freshwater calving glaciers have shown a linear relationship between ice-flow speed and lake water depth (e.g. Funk and Röthlisberger, 1989; Van der Veen, 2002). Both acceleration and calving cause more ice to be dissipated, reducing the thickness of the glacier. At Tasman Glacier, New Zealand, Kirkbride and Warren (1999) observed acceleration and rapid thinning followed by an increase in the calving rate. Ice thinning is also important for the basal sliding, which is controlled by the effective pressure $P_{\mathrm{e}}=P_{\mathrm{i}}-P_{\mathrm{w}}$, where $P_{\mathrm{i}}$ and $P_{\mathrm{w}}$ are the ice overburden and subglacial water pressures, respectively. Observations in mountain glaciers suggest that the basal sliding increases as the effective pressure decreases (e.g. Bindschadler, 1983). Assuming that the subglacial water pressure is constant near a lake, the effective pressure decreases as the ice thins. Another important mechanism at the lake front is break-up of the glacier terminus caused by the buoyancy force of lake water. It may occur when the subglacial water pressure exceeds the ice overburden pressure. Sudden uplift and break-off events have been observed at several glaciers (Müller, 2004; Walder and others, 2005, 2006; Sugiyama and others, 2008b). Field studies on the front dynamics of lake calving glaciers have been conducted in Patagonia (e.g. Rott and others, 1998; Warren and others, 2001; Skvarca and others, 2003), New Zealand (e.g. Kirkbride and Warren, 1999; Quincey and Glasser, 2009) and the Himalaya
(Luckman and others, 2007; Bolch and others, 2008). However, to gain deeper insights into the mechanisms controlling glacier dynamics, it is also important to carry out high-resolution measurements of glaciers in the process of lake formation. The marginal lakes forming in Rhonegletscher, Switzerland provide such an opportunity (Fig. 1). These lakes began forming when the glacier retreated behind a bump in the bedrock, and the ice has been thinning at an increasing rate ever since (Sugiyama and others, 2008a). Because the glacier is located near paved roadways, its retreat and the formation of the lake have drawn many tourists and considerable public attention.

To investigate the impact of proglacial lake formation on ice dynamics and glacier evolution, we carried out intensive field measurements near the terminus of Rhonegletscher during the 2007-09 summer seasons. The flow speed and vertical ice motion were measured with high spatial resolution in each year and compared with reported data taken in years before the lake formed. Surface and bed elevations in the region were measured by GPS surveys and by drilling boreholes with a hot-water technique. We measured significant changes in the horizontal flow speed over time, which can be attributed to lake development and glacier thinning. The flow speed is significantly larger after lake formation. Observations taken in the summers of 2008 and 2009 reveal that the glacier surface rose by $>2.8 \mathrm{~m} \mathrm{a}^{-1}$, probably because the thinner ice is afloat. These results confirm the important impact of lake formation on glacier dynamics and glacier thinning. Our observations suggest that Rhonegletscher will continue to retreat at an increasing rate.

\section{FIELD MEASUREMENTS}

\section{Study site}

Rhonegletscher is a temperate valley glacier in the Swiss Alps with an area of $15.12 \mathrm{~km}^{2}$ (Farinotti and others, 2009). The glacier terminus retreated $1700 \mathrm{~m}$ between 1878 and 

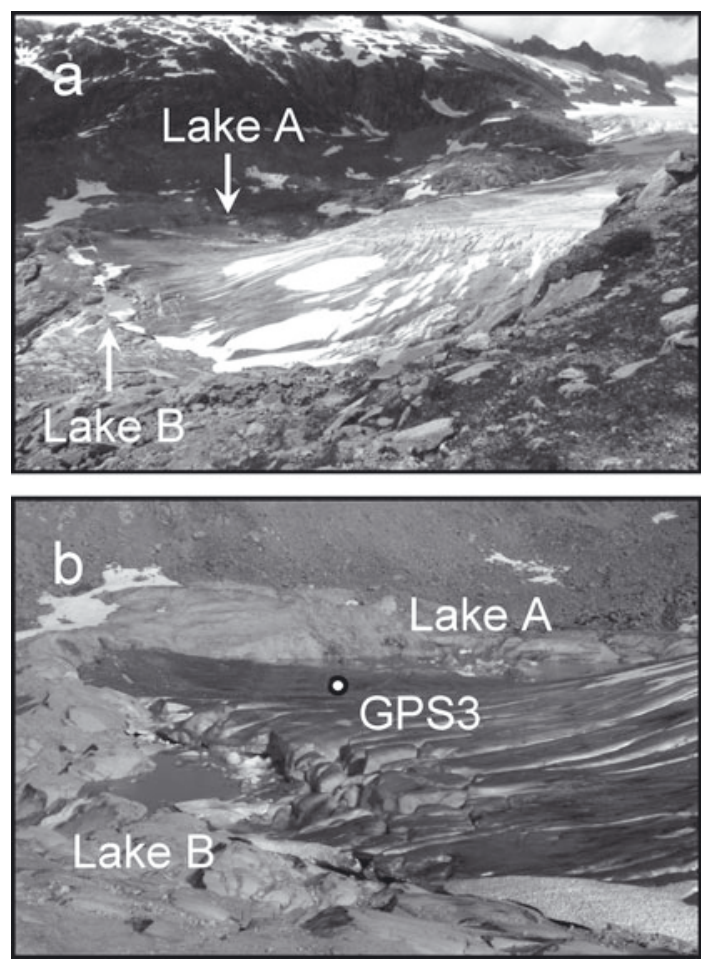

Fig. 1. Photographs showing (a) the study area and (b) the proglacial lakes viewed from the southeast. The approximate location of GPS3 is indicated. The photographs were taken on (a) 6 July 2009 and (b) 16 July 2009

2000 (Sugiyama and others, 2011), and its cumulative mean specific net balance during the period 1865-2006 has been calculated as $\sim-40 \mathrm{~m}$ w.e. (Huss and others, 2008). Zahno (2004) measured the ice thickness along 12 transverse profiles by radio-echo soundings and constructed a bed elevation map by interpolation. Nishimura (2008) recently measured the surface flow velocity distribution for the period 1970-2006 by analysing aerial photographs. One of the recently formed proglacial lakes, referred to as lake $A$ in this paper, has existed since the late 1990s. It is located at the northwestern margin of the glacier (Figs 1 and 2). The other lake (lake B) consists of ponding meltwater dammed by the bedrock bump and appeared in 2005 (Figs 1 and 2).

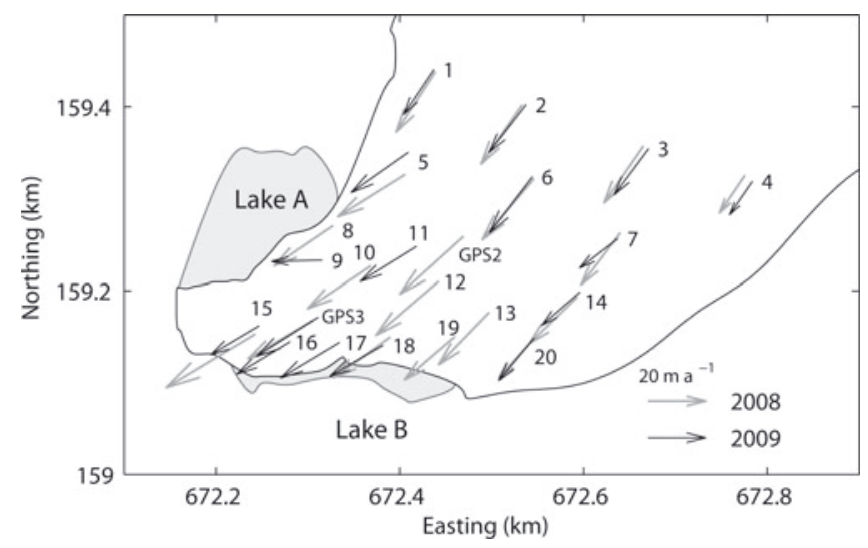

Fig. 2. Horizontal flow vectors measured in 2008 (grey, bold) and 2009 (black, thin). The two proglacial lakes are indicated by the shaded areas. The coordinates correspond to the official Swiss coordinate system.

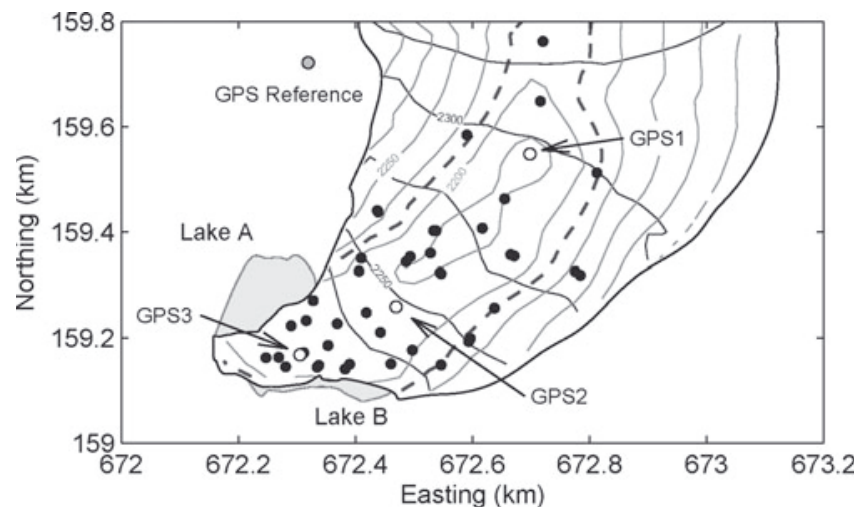

Fig. 3. Map of the study site with surface (black) and bedrock (grey) elevations. The contours are drawn at intervals of $25 \mathrm{~m}$. Along the dotted line, the bed elevation is equal to the lake level. The surface elevations are based on DEMs constructed from our GPS kinematic survey in 2009, and the bed elevations are based on boreholes drilled from 2007 to 2009. The locations of GPS1-3 (о) and boreholes $(\bullet)$ are indicated.

As shown in Figure 1b, ice blocks broke into lake B during the 2007-09 summer seasons. The level of lake B is nearly constant because excess water spills over the rock ridge. The two lakes are separated by the glacier, but their levels are almost the same $(2211.4 \mathrm{~m})$ according to measurements taken on 29 August 2008 and 2 September 2009. All our field activities were carried out in a region within $800 \mathrm{~m}$ of the glacier terminus in the 2007-09 summer seasons (Fig. 3; see also fig. 1 in Sugiyama and others, 2011).

\section{Glacier motion}

We measured the surface motion of the glacier by surveying 23 stakes (aluminium poles $4.0-6.0 \mathrm{~m}$ long) installed in the ice at the locations indicated in Figures 2 and 3, referred to as stakes 1-20 and GPS1-3. We used dual-frequency GPS receivers and antennae (Leica System 1200) to measure the three-dimensional (3-D) positions of the stakes. One antenna was fixed to solid rock on the western bank of the glacier as a reference station (Fig. 3). Another antenna was mounted on all the stakes and operated for 20-30 min every 2 weeks. These static-mode data were processed by GPS software (Leica Geo Office) to compute the 3-D position of each stake. From 14 July to 6 September 2007, the GPS measurements were carried out only at stakes GPS1-3. The measurements at stakes 1-20 were conducted in addition to GPS1-3 on 18 July and 7 September 2008 and on 27 June and 6 September 2009. According to control experiments with similar GPS devices, the positioning errors of the static survey are $2 \mathrm{~mm}$ in the horizontal and $3 \mathrm{~mm}$ in the vertical direction (Sugiyama and Gudmundsson, 2004). Measurement errors due to the tilting of the stake by ice melt or wind are about $10-20 \mathrm{~mm}$. This error is $<3 \%$ of the total stake displacement over each survey interval for three seasons.

\section{Surface elevation}

The glacier surface elevation was surveyed on 27 and 31 July 2008 and on 12 and 29 July 2009. We used the same GPS devices, this time operating in kinematic mode, to measure more than 200 locations in the study area. The positioning errors in the horizontal and vertical directions are $<20 \mathrm{~mm}$ according to the GPS software used for the processing. Errors due to the ice surface roughness are 


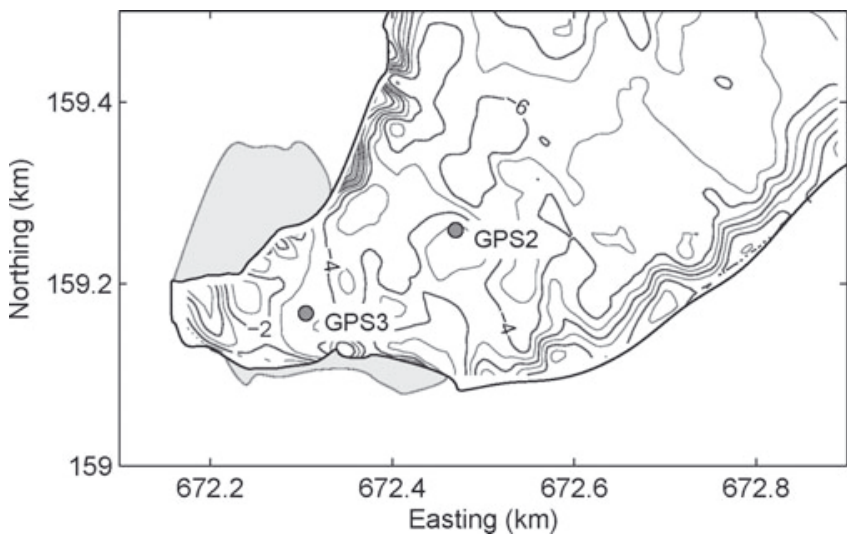

Fig. 4. Changes in the surface elevation from 31 July 2008 to 29 July 2009, as measured by the GPS kinematic survey. The intervals of thin and thick contour lines are 1 and $2 \mathrm{~m}$, respectively.

$\sim 100 \mathrm{~mm}$. We used the same technique to survey the glacier and lake margins on 26 July, 27 July and 7 August 2008 and on 12 July and 29 July 2009.

\section{Ice thickness}

In the 2007-09 summer seasons, we drilled 51 boreholes in the survey region using a hot-water technique (Fig. 3) (for details on hot-water drilling, see Sugiyama and others, 2008a; Tsutaki and Sugiyama, 2009). We measured the ice thickness with the length of the hose used for the drilling. The accuracy of the thickness is 1-2 $\mathrm{m}$ because of stretching of the hose during the drilling (Tsutaki and Sugiyama, 2009). The ice thickness was also measured with a tape measure lowered into some of the boreholes with a weight attached to its end. The accuracy of this measurement is $20 \mathrm{~mm}$. Bedrock elevation was calculated from the ice thickness and the surface elevation measured by the kinematic GPS survey. We constructed a bedrock elevation map with $25 \mathrm{~m}$ resolution by interpolating the bed elevations obtained at the drilling sites (Fig. 3).

\section{RESULTS}

\section{Horizontal and vertical velocity}

The surface flow velocity fields in the summers of 2008 and 2009 are shown in Figure 2 and listed in Table 1. In 2008, the greatest velocity observed was $35.92 \mathrm{~m} \mathrm{a}^{-1}$ at stake 15 which lies very close to the terminus. The velocity was generally larger near the terminus than in the upper reaches. For example, the velocities of stakes $10\left(26.38 \mathrm{~m} \mathrm{a}^{-1}\right)$ and 13 $\left(25.13 \mathrm{~m} \mathrm{a}^{-1}\right)$ were $6 \%$ greater than those of stakes 2 $\left(24.92 \mathrm{~m} \mathrm{a}^{-1}\right)$ and $3\left(23.81 \mathrm{~m} \mathrm{a}^{-1}\right)$. From stake 10 to stake 15 the velocity increases by $36 \%$ over a distance of $150 \mathrm{~m}$. In 2009, the velocity at stake 15 was 46\% less than in 2008 . The upper reaches also decelerated: the velocities of stakes 1-4 diminished by an average of $18 \%$. Despite this trend, the ice at the lake front still flowed rapidly in 2009. The velocities at stakes $16\left(21.52 \mathrm{~m} \mathrm{a}^{-1}\right), 17\left(23.79 \mathrm{ma}^{-1}\right)$ and $18\left(21.23 \mathrm{~m} \mathrm{a}^{-1}\right)$ are large compared to those observed at the termini of other valley glaciers of similar size. Very large upwards motion was observed at the stakes located near the lake front. The vertical velocities of stakes 9,15 and 16 were $>20 \mathrm{~m} \mathrm{a}^{-1}$ in 2009 (Table 1). The data for stake 15 show that the ice moved upwards by a similar magnitude in 2008 .
Table 1. Horizontal $\left(u_{h}\right)$ and vertical velocities $\left(u_{z}\right)$ measured in the summers of 2008 (18 July-7 September) and 2009 (27 June6 September)

\begin{tabular}{lcccc}
\hline Stake No. & & 2008 & & \multicolumn{2}{c}{2009} \\
& $u_{h}$ & $u_{z}$ & $u_{h}$ & $u_{z}$ \\
& $\mathrm{ma}^{-1}$ & $\mathrm{ma}^{-1}$ & $\mathrm{~m} \mathrm{a}^{-1}$ & $\mathrm{~m} \mathrm{a}^{-1}$ \\
\hline GPS2 & 29.62 & -5.10 & - & - \\
GPS3 & 25.93 & 2.89 & 25.60 & 4.60 \\
1 & 24.82 & -3.65 & 18.71 & -3.57 \\
2 & 24.92 & -1.28 & 20.92 & -2.99 \\
3 & 23.81 & -2.47 & 19.94 & -1.13 \\
4 & 15.69 & -3.81 & 13.91 & -3.12 \\
5 & 27.45 & -10.48 & 24.20 & -11.16 \\
6 & 27.59 & -3.79 & 24.34 & -2.58 \\
7 & 22.54 & -3.91 & 16.68 & -4.86 \\
8 & 24.65 & 1.28 & - & - \\
9 & - & - & 17.45 & 26.10 \\
10 & 26.38 & -7.07 & - & - \\
11 & - & - & 22.90 & -11.05 \\
12 & 28.55 & -7.51 & - & - \\
13 & 25.13 & -5.97 & - & - \\
14 & 22.84 & -5.76 & 17.47 & -7.04 \\
15 & 35.92 & 23.07 & 19.44 & 20.27 \\
16 & - & - & 21.52 & 20.60 \\
17 & - & - & 23.79 & -0.39 \\
18 & 23.99 & 4.65 & 21.23 & -0.97 \\
19 & 23.03 & -2.47 & - & - \\
20 & 18.21 & -5.20 & 19.13 & -5.78 \\
& & & & \\
\hline & & & &
\end{tabular}

The vertical velocity at GPS3 increased from $2.89 \mathrm{ma}^{-1}$ in 2008 to $4.60 \mathrm{~m} \mathrm{a}^{-1}$ in 2009 . The ice motion was downwards at all other stakes in the studied region.

\section{Bed and surface elevation}

Figure 3 shows the glacier bed contour map together with surface elevation contours for 2009. The maximum ice thickness in the region was $\sim 130 \mathrm{~m}$ near GPS1. A depression in the bedrock $30-40 \mathrm{~m}$ deep exists along the valley centre beneath GPS1 and GPS2. In regions where the surface elevation is $<2250 \mathrm{~m}$, the ice thickness is $<70 \mathrm{~m}$. The glacier margins bordering lakes A and B were $\sim 26$ and 14 m thick, respectively. Figure 4 shows the change in the surface elevation from 31 July 2008 to 29 July 2009. The elevation lowered by $1-6 \mathrm{~m}$ in the study area over the year. The magnitude of the elevation change is greatest in the upper reaches and decreases towards the terminus. The maximum change of $-6 \mathrm{ma}^{-1}$ was observed about $100 \mathrm{~m}$ north of GPS2. The mean thinning rates at surface elevations of 2200-2250 and 2250-2350 $\mathrm{m}$ are -2.15 and $-3.44 \mathrm{~m} \mathrm{a}^{-1}$, respectively. If we compare data observed within the same elevation range, the change was slightly greater on the western side of the glacier.

\section{DISCUSSION}

The velocity field at the terminal part of Rhonegletscher is significantly faster than terminal flows observed in similar glaciers without proglacial lakes. This difference is probably due to the influence of lake water. The water level of lake A was $\sim 1.7 \mathrm{~m}$ below the ice surface in 2008, indicating that $102 \%$ of the ice overburden pressure was cancelled by the 

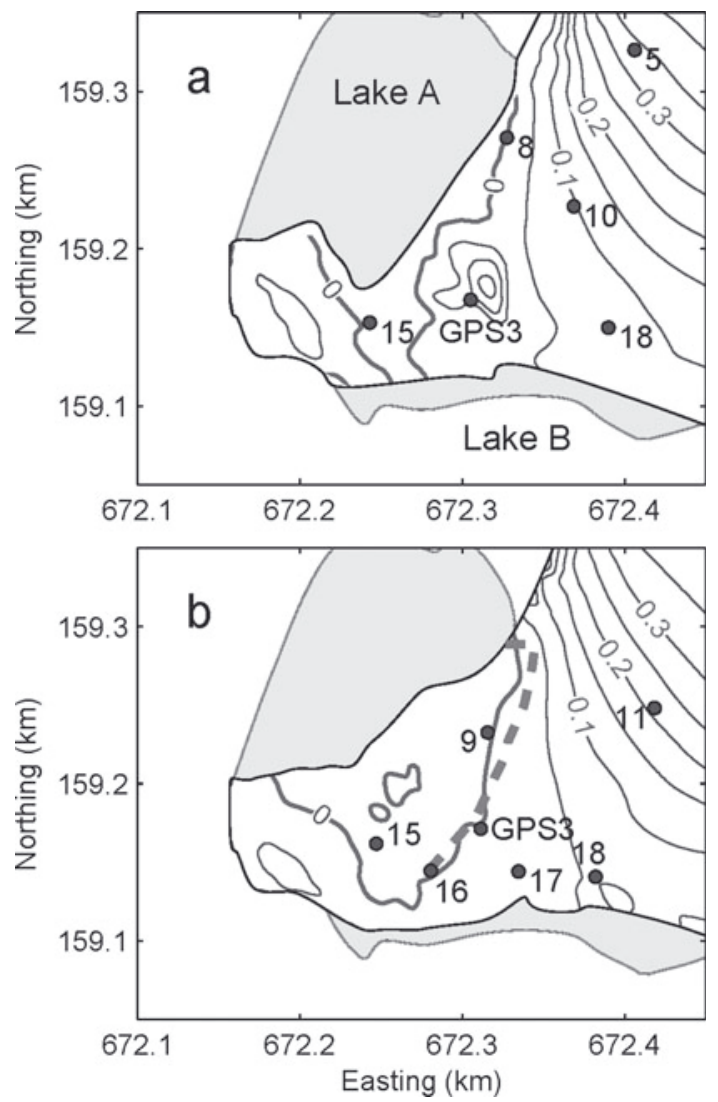

Fig. 5. The effective pressure in MPa in (a) 2008 and (b) 2009. The contour intervals are $0.05 \mathrm{MPa}$. The ice overburden pressure was calculated from the surface and bed DEMs constructed in this study. The dashed line in (b) indicates the crevassed zone described in the text and depicted in Figure 6.

lake water pressure. The small effective pressure near the terminus creates favourable conditions for basal sliding (e.g. Bindschadler, 1983). For example, the ice thickness at GPS3 in 2008 was $20 \mathrm{~m}$ and the estimated surface flow speed due to vertical shearing for this thickness is only several millimetres per year (Paterson, 1994). Thus, nearly 100\% of the surface flow observed in this study was caused by basal ice motion. The velocities near lakes $\mathrm{A}$ and $\mathrm{B}$ are comparable with those in the upper reaches (Fig. 2; Table 1). In this respect, the behaviour of Rhonegletscher is similar to that of Mendenhall Glacier, Alaska, (Motyka and others, 2002). The flow regime near the terminus was tensile. The longitudinal strain rate between stakes 10 and 15 was $0.064 \mathrm{a}^{-1}$ in 2008, suggesting substantial glacier thinning due to ice dynamics. We investigate the influence of lake formation on the ice flow speed by comparing our observations at GPS1, GPS2 and GPS3 from 2007 to 2009 with previous studies from 1999-2000 and 2005-06 (Nishimura, 2008). Note that our measurements are of summer velocities only, while the reported data represent annual velocities. Nevertheless, a significant acceleration of the terminus after lake formation is evident (Table 2). The flow velocity at GPS3 more than tripled from 2006 to 2007. This change cannot be attributed to seasonal variations, because the upper reaches of the glacier at GPS1 accelerated slightly during the same period. The velocity at GPS3 increased by $18 \%$ from 2007 to 2008 and became steady in 2009. At GPS2, $350 \mathrm{~m}$ from the terminus, the velocity increased by $35 \%$ from 2006 to 2008. The accelerations at GPS2 and GPS3 both occurred over a period of 1-2 years after the first recognition of lake B in 2005. It is apparent that the formation and development of the lake triggered the changes in the flow regime near the terminus.

The huge surface uplift observed at stakes 9, 15 and 16 was most likely due to flotation of the glacier in the lake. (The terminus of a calving glacier may float when the subglacial water pressure reaches the ice overburden pressure, as described in the introduction.) To examine whether the conditions for floating are met in Rhonegletscher, we compute the effective pressure distribution, $P_{\mathrm{e}}$ :

$$
P_{\mathrm{e}}=\rho_{\mathrm{i}} \mathrm{g}\left(z_{\mathrm{s}}-z_{\mathrm{b}}\right)-\rho_{\mathrm{w}} \mathrm{g}\left(z_{\mathrm{w}}-z_{\mathrm{b}}\right),
$$

where $\rho_{\mathrm{i}}=910 \mathrm{~kg} \mathrm{~m}^{-3}$ and $\rho_{\mathrm{w}}=1000 \mathrm{~kg} \mathrm{~m}^{-3}$ are ice and water densities, respectively, and $g=9.81 \mathrm{~m} \mathrm{~s}^{-2}$ is the gravitational acceleration. The lake level, $z_{w}=2211.4 \mathrm{~m}$, is assumed to be constant and the ice surface $\left(z_{s}\right)$ and bed elevations $\left(z_{\mathrm{b}}\right)$ are given by the digital elevation models (DEMs) constructed in this study (Fig. 3). In 2008, the effective pressure reached zero at the shore of lake $\mathrm{A}$ and an area including stake 15 (Fig. 5a). This region extended to the southeast in 2009 as a result of glacier thinning (Fig. 5b). Accordingly, a crevassed zone began to form along the northern margin of lake A towards stake 16 (dotted line in Fig. 5b) in late July 2009; see Figure 6a for a photograph of this zone. The northwestern side of the crevassed zone had gradually risen above the southeastern side (by $\sim 4 \mathrm{~m}$ in surface elevation) by the beginning of September (Fig. 6b and c). Stakes 9, 15 and 16 were located on the ice that moved upwards. GPS3 was on the other side, but only a few metres from the crevassed zone. The upwards motion at GPS3 can be explained by mechanical coupling to the floating part of the ice: the so-called cantilever effect (Nye, 1976). These observations suggest that if the glacier

Table 2. Annual flow velocities for the periods $1999-2000$ and 2005-06 and summer flow velocities for 2007-09 at the measurement sites GPS1-3 shown in Figure 3; the presumed annual flow velocities after 2007 are shown in parentheses

\begin{tabular}{|c|c|c|c|c|}
\hline Period & $\begin{array}{l}\text { GPS1 } \\
\mathrm{m} \mathrm{a}^{-1}\end{array}$ & $\begin{array}{l}\text { GPS2 } \\
\mathrm{ma}^{-1}\end{array}$ & $\begin{array}{l}\text { GPS3 } \\
\mathrm{m} \mathrm{a}^{-1}\end{array}$ & Source \\
\hline 2009 & - & - & $25.60(15.87)$ & This study \\
\hline 2008 & $27.31(16.93)$ & $29.62(18.36)$ & $25.93(16.08)$ & This study \\
\hline 2007 & $26.83(16.64)$ & - & $22.00(13.64)$ & This study \\
\hline 2005-06 & 25 & 22 & 7 & Nishimura (2008) \\
\hline 1999-2000 & 30 & 20 & 5 & Nishimura (2008) \\
\hline
\end{tabular}


continues to thin, this entire section of the terminus may float and disintegrate over the next few years.

The thinning rate at elevations of 2250-2350 m during the period 1991-2000 was $1.87 \mathrm{~m} \mathrm{a}^{-1}$, based on a comparison of DEMs constructed from aerial photographs (Zahno, 2004). Sugiyama and others (2008a) reported that the rate had increased to a value of $2.75 \mathrm{~m} \mathrm{a}^{-1}$ from 2000 to 2007 . The value of $3.44 \mathrm{ma}^{-1}$ obtained in this study for the same elevation range shows that the glacier is thinning at a progressively increasing rate in the 21 st century. At a constant thinning rate of $3.4 \mathrm{ma}^{-1}$, the lake will continue to expand up-glacier and will reach the location of GPS1 in 2034, 6 years earlier than the prediction of Sugiyama and others (2008a). The increase in the thinning rate is consistent with observed mass-balance changes in Swiss glaciers. Huss and others (2008) computed the seasonal mass balance of four glaciers, including Rhonegletscher, for the period 1865 2006. According to their results, the rate of mass loss progressively increased after a short period of mass gain from 1974 to 1981. The period 1998-2006 was characterized by strongly negative mass balance in all four glaciers. The bed elevation map shown in Figure 3 is important for predicting future expansion of the proglacial lake. We predict that the lake will expand nearly $1 \mathrm{~km}$ from the current terminus to the area bounded by the dotted line as the glacier retreats. The maximum depth of the lake upon reaching this size will be $\sim 60 \mathrm{~m}$. A sudden outburst of the lake water is not likely as it is dammed by the bedrock bump, but the glacier dynamics will be influenced by the lake water as long as the glacier is in contact with the lake.

\section{CONCLUSION}

We studied the impact of proglacial lake formation on ice dynamics and glacier evolution at Rhonegletscher. The flow speed and vertical motion of the terminal part of the glacier were measured at high spatial resolution during the 200709 summer seasons. The surface flow velocity near the terminus was fairly large, and its magnitude was similar to the velocity in the upper reaches. Horizontal velocities greater than $20 \mathrm{~m} \mathrm{a}^{-1}$ were observed in the region where the ice thickness was only $\sim 20 \mathrm{~m}$. Thus, most of the flow at the terminus was due to basal ice motion. The area was exposed to a very large tensile longitudinal strain, which indicates that a substantial portion of the thinning was due to ice dynamics. Comparisons of our data to studies performed in 1999-2000 and 2005-06 reveal that the flow velocity approximately tripled from 2006 to 2007. It is most likely that the formation and development of the lake triggered this increase in the flow speed. Analysis of the effective pressure confirms that water pressure exceeded the ice overburden pressure in 2008 along the shore of lake A. The region of excess water pressure extended even further under the glacier in 2009 as a result of ice thinning. In the vicinity of the lake, the ice surface moved upwards at a rate greater than $20 \mathrm{ma}^{-1}$ in 2009 . This motion is related to the formation of a crevassed zone in the marginal ice, which moved upwards by $\sim 4 \mathrm{~m}$ over the summer of 2009 . It is likely that the entire glacier terminus will float and disintegrate over the next few years if the ice continues to thin. In the elevation range $2250-2350 \mathrm{~m}$, the glacier is thinning at a progressively increasing rate. Assuming that the thinning rate of $3.4 \mathrm{~m} \mathrm{a}^{-1}$ observed in 2008-09 is sustained,
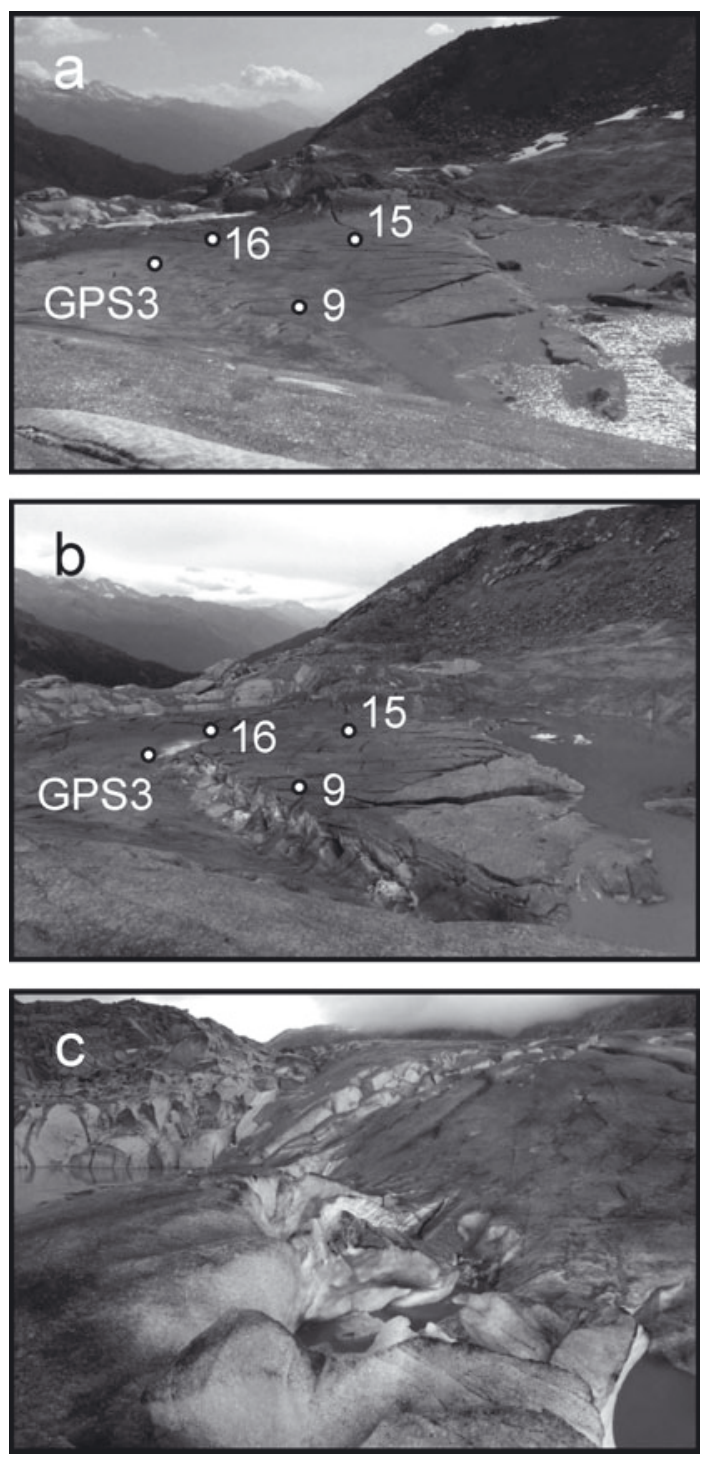

Fig. 6. (a, b) Photographs of the terminus of Rhonegletscher on (a) 29 July 2009 and (b) 3 September 2009. The approximate locations of survey stakes are indicated. (c) Photograph of the crevassed zone near stake 9, viewed from the southwest.

the glacier will retreat approximately $600 \mathrm{~m}$ and the lake will expand to its maximum size by 2034 .

\section{ACKNOWLEDGEMENTS}

We thank M. Funk, H. Blatter, A. Bauder, T. Wyder, A. Keller, G. Turi and F. Lehner for their help in the field. Materials for the field campaign were loaned by the Section of Glaciology, Swiss Federal Institue of Tchnology (VAW), ETH Zürich. We thank an anonymous referee for providing careful reviews and the scientific editor, D. MacAyeal, for handling the paper. This research was funded by the Japanese Ministry of Education, Science, Sports and Culture through a Grant-inAid for Young Scientists (Start-up), 18840002, 2006-07 and by a Grant-in-Aid for Scientific Research C (Capital), 20540418, 2008-10. Additional funding was provided by an internal programme of the Institute of Low Temperature Science, Hokkaido University, by the Inoue Scientific Field Study Foundation and by the Global Centre of Excellence Program (Establishment of Centre for Integrated Field Environmental Science), MEXT, Japan. 


\section{REFERENCES}

Bindschadler, R. 1983. The importance of pressurized subglacial water in separation and sliding at the glacier bed. J. Glaciol., 29(101), 3-19.

Bolch, T., M.F. Buchroithner, J. Peters, M. Baessler and S. Bajracharya. 2008. Identification of glacier motion and potentially dangerous glacial lakes in the Mt. Everest region/ Nepal using spaceborne imagery. Natur. Hazards Earth Syst. Sci. (NHESS), 8(6), 1329-1340.

Boyce, E.S., R.J. Motyka and M. Truffer. 2007. Flotation and retreat of a lake-calving terminus, Mendenhall Glacier, southeast Alaska, USA. J. Glaciol., 53(181), 211-224.

Clague, J.J. and S.G. Evans. 2000. A review of catastrophic drainage of moraine-dammed lakes in British Columbia. Quat. Sci. Rev., 19(17-18), 1763-1783.

Farinotti, D., M. Huss, A. Bauder, M. Funk and M. Truffer. 2009. A method to estimate ice volume and ice-thickness distribution of alpine glaciers. J. Glaciol., 55(191), 422-430.

Funk, M. and H. Röthlisberger. 1989. Forecasting the effects of a planned reservoir which will partially flood the tongue of Unteraargletscher in Switzerland. Ann. Glaciol., 13, 76-81.

Huss, M., A. Bauder, M. Funk and R. Hock. 2008. Determination of the seasonal mass balance of four Alpine glaciers since 1865. J. Geophys. Res., 113(F1), F01015. (10.1029/ 2007JF000803.)

Kirkbride, M.P. and C.R. Warren. 1999. Tasman Glacier, New Zealand: 20th-century thinning and predicted calving retreat. Global Planet. Change, 22(1-4), 11-28.

Luckman, A., D.J. Quincey and S. Bevan. 2007. The potential of satellite radar interferometry and feature tracking for monitoring flow rates of Himalayan glaciers. Remote Sens. Environ., 111(2-3), 172-181.

Motyka, R.J., S. O'Neel, C.L. Connor and K.A. Echelmeyer. 2002. 20th century thinning of Mendenhall Glacier, Alaska, and its relationship to climate, lake calving, and glacier run-off. Global Planet. Change, 35(1-2), 93-112.

Müller, B. 2004. Veränderung des Triftgletschers seit 1861: Untersuchung der Stabiltätsveränderung in der Steilstufe. (Diploma thesis, ETH Zürich.)

Naruse, R. and P. Skvarca. 2000. Dynamic features of thinning and retreating Glaciar Upsala, a lacustrine calving glacier in southern Patagonia. Arct. Antarct. Alp. Res., 32(4), 485-491.

Nishimura, D. 2008. Changes in surface flow speed over the past 100 years, Rhonegletscher, Swiss Alps. (Master thesis, Hokkaido University.)

Nye, J.F. 1976. Water flow in glaciers: jökulhlaups, tunnels and veins. J. Glaciol., 17(76), 181-207.
Paterson, W.S.B. 1994. The physics of glaciers. Third edition. Oxford, etc., Elsevier.

Post, A. and L.R. Mayo. 1971. Glacier dammed lakes and outburst floods in Alaska. USGS Hydrol. Invest. Atlas HA-455.

Quincey, D.J. and N.F. Glasser. 2009. Morphological and icedynamical changes on the Tasman Glacier, New Zealand, 19902007. Global Planet. Change, 68(3), 185-197.

Rott, H., M. Stuefer, A. Siegel, P. Skvarca and A. Eckstaller. 1998. Mass fluxes and dynamics of Moreno Glacier, Southern Patagonia Icefield. Geophys. Res. Lett., 25(9), 1407-1410.

Skvarca, P., B. Raup and H. De Angelis. 2003. Recent behaviour of Glaciar Upsala, a fast-flowing calving glacier in Lago Argentino, southern Patagonia. Ann. Glaciol., 36, 184-188.

Sugiyama, S. and G.H. Gudmundsson. 2004. Short-term variations in glacier flow controlled by subglacial water pressure at Lauteraargletscher, Bernese Alps, Switzerland. J. Glaciol., 50(170), 353-362.

Sugiyama, S., S. Tsutaki, D. Nishimura, H. Blatter, A. Bauder and M. Funk. 2008a. Hot water drilling and glaciological observations at the terminal part of Rhonegletscher, Switzerland in 2007. Bull. Glaciol. Res., 26, 41-47.

Sugiyama, S., A. Bauder, M. Huss, P. Riesen and M. Funk. $2008 \mathrm{~b}$. Triggering and drainage mechanisms of the 2004 glacierdammed lake outburst in Gornergletscher, Switzerland. J. Geophys. Res., 113(F4), F04019. (10.1029/2007JF000920.)

Sugiyama, S., T. Yoshizawa, M. Huss, S. Tsutaki and D. Nishimura. 2011. Spatial distribution of surface ablation in the terminus of Rhonegletscher, Switzerland. Ann. Glaciol., 52(58) (see paper in this issue).

Tsutaki, S. and S. Sugiyama. 2009. Development of a hot water drilling system for subglacial and englacial measurements. Bull. Glaciol. Res., 27, 7-14.

Van der Veen, C.J. 2002. Calving glaciers. Progr. Phys. Geogr., 26(1), 96-122.

Walder, J.S. and 6 others. 2005. Fault-dominated deformation in an ice dam during annual filling and drainage of a marginal lake. Ann. Glaciol., 40, 174-178.

Walder, J.S. and 6 others. 2006. Local response of a glacier to annual filling and drainage of an ice-marginal lake. J. Glaciol., 52(178), 440-450.

Warren, C., D. Benn, V. Winchester and S. Harrison. 2001. Buoyancy-driven lacustrine calving, Glaciar Nef, Chilean Patagonia. J. Glaciol., 47(156), 135-146.

Yamada, T. 1998. Glacier lake and its outburst flood in the Nepal Himalaya. Tokyo, Japanese Society of Snow and Ice. Data Center for Glacier Research.

Zahno, C. 2004. Der Rhonegletscher in Raum und Zeit: neue geometrische und klimatische Einsichten. (Diploma thesis, ETH Zürich.) 